\title{
Characteristics Of The Marble Industry In Egypt: Structure, Conduct, And Performance
}

Azza I. Kandil, Canadian International Development Agency, Egypt Tarek H. Selim, (Email: tselim@ aucegypt.edu), American University in Cairo, Egypt

\begin{abstract}
This paper analyzes marble extraction and production in Egypt from an applied industrial economics point of view. The marble industry in Egypt could be a promising sector if regulated properly. Market structure, conduct and performance is analyzed including degree of differentiation, nature of competition, barriers to entry, and needed regulations. Technically, production matches increasing returns of a Cobb Douglas form $Q(K, L)=K^{0.89} L^{1.33}$ while cost structure follows declining average cost with entry $C(Q)=\gamma Q^{-0.55}$. Factor inputs in production are non-complementary with $\$ 1000$ of capital substitutable by 7.5 units of labor. Efficiency concerns necessitate deep technological segmentation with declining profitability. Critically needed regulations are related to technological use in extraction and labor allocation in production. For higher efficiency, the industry should become more capital intensive even though the Egyptian economy is undeniably labor abundant.
\end{abstract}

\section{INTRODUCTION}

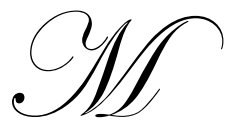

arble is a precious ornamental stone used by man very early in history. It could be said that marble quarrying and processing industries belong to the oldest industries of the world. The Ancient Egyptians, 5000 years ago, knew 40 different types of ornamental stones and worked chiefly with granite and some types of marble such as Alabaster. Some historians assert that the Greek and the Romans acquired the skills of quarrying and processing marble from the Ancient Egyptians. For over a thousand years now, the economic activity of a city like Carara in Italy has been relying on and revolving mainly around marble.

Today, marble is a differentiated product that is internationally traded. The price and value of marble depends on one hand on its natural characteristics (like quality, type and color) and on the other hand on technological processing (giving it a special shape, polish, size and thickness). Hence, the production of marble can be considered as (1) highly differentiated, and (2) strongly dependent on level of technology use. For a country to lead in this industry, it needs to be rich in the natural endowments of this precious stone as well as to possess a good technological base that could allow it to properly extract and process marble for local and international trading.

The objective of this paper is to study the characteristics of the marble industry in Egypt from an industrial economics viewpoint with firm-level application. Specifically, the research is directed to study the Egyptian marble industry with respect to market structure, product quality and characteristics, economic performance, as well as future prospects, critical impediments and needed regulations. In general, there is very little published information on the Egyptian marble industry, therefore lots of field research was conducted and extensive interviews were held with industry entrepreneurs, geologists, as well as suppliers of equipment for the industry, in addition to credit and finance officers in banks. Subsequently, representative firm analysis was conducted based on the following criteria: (1) medium-size enterprise with accessibility to both local and export markets (most of the firms in the industry are medium size), and (2) established after the 1980s in order to represent the generation of marble producers that evolved during that time and shaped this industrial sector over the past twenty years, in terms of technology used. 


\section{MARBLE QUARRIES}

Marble quarries are found in different locations all over the country, along the coast of the Red Sea (Zafarana), Sinai, Menia, Assiut, Aswan and the Eastern Desert. Experts confirm that Egypt has big reserves of undiscovered marble. Table (1) specifies the type of marble available in different marble quarries as a natural resource in Egypt and gives a description of each type. It also states the commercial name of the marble extracted which is not necessarily its scientific name. The name "Black Carrara" is an example for such a discrepancy. Carrara marble is one of the most famous Italian marble in the world. Giving Egyptian marble this name indicates that this Egyptian marble resembles the Italian Carrara but with a black color. It is noteworthy to mention that Carrara is by default white. Table (1) reflects that Egyptian marble has a wide variety of colors which is an important determinant to its price, quality, and ultimately, economic value.

Currently, Egypt has about 500 marble and granite factories. According to specialists in the industry, there are three types of factories: (1) factories that are involved in cutting blocks into plates of marble and then distributing them to workshops that handle further cutting and polishing, (2) factories that cut and polish the plates, and (3) factories that do the whole process until the final product is produced. The area of "Shak El Thoban" in Katameyya has become a conglomeration of factories working in the marble and granite industry. This area was first occupied by quarrymen quarrying the limestone in the hills and mountains of Katameyya. Over time, interested investors in this area were granted about $10,000 \mathrm{~m}^{2}$ for the price of $\$ 12$ per $\mathrm{m}^{2}$ to build their stone factories. Quarrymen who started to work in the limestone hills switched their stone factories to work in marble and granite which proved more profitable.

Table 1: Location Of Marble Quarries In Egypt

\begin{tabular}{|c|c|c|c|}
\hline Type & Location & Commercial Name & Specifications \\
\hline White Marble & $\begin{array}{c}\text { Wady el Elaky - Wady El } \\
\text { Miyah }\end{array}$ & White Carrara & $\begin{array}{c}\text { White with black and red } \\
\text { veins }\end{array}$ \\
\hline Black Marble & $\begin{array}{c}\text { Wady el Elaky-North } \\
\text { Albaramia-Wadi El Miyah }\end{array}$ & Black Carrara & Black with white veins \\
\hline $\begin{array}{c}\text { Calcic stone (Marble } \\
\text { substitute) }\end{array}$ & $\begin{array}{c}\text { Assiout and Kharga- } \\
\text { Zafarana-- East of Sohag }\end{array}$ & Berlato & $\begin{array}{c}\text { White \& dark cream, } \\
\text { yellowish cream }\end{array}$ \\
\hline $\begin{array}{c}\text { Calcic stone (Marble } \\
\text { substitute) }\end{array}$ & $\begin{array}{c}\text { Wadi Fyran, Sinai- } \\
\text { Zaafarana-El Koraymat- El } \\
\text { Galala }\end{array}$ & Botshino & Reddish pink \\
\hline Green Serabantin & $\begin{array}{c}\text { Wady Atallah AlKoser - Om } \\
\text { Hassan Mountain, desert }\end{array}$ & Green Marble & Dark Green with veins \\
\hline $\begin{array}{c}\text { Calcic stone (Marble } \\
\text { substitute) }\end{array}$ & Balk upper Egypt- Alhasna & Fleto Rosso & Cream with brownish veins \\
\hline Green Brishia Ferdy & $\begin{array}{c}\text { Wady el Hamamat -Gabal El } \\
\text { Dokhan, }\end{array}$ & Green Brishia & Dark and light Green \\
\hline Red Brishria & Assiout - Sohag & Red Brishia & Dark and light Red \\
\hline Alalbastar & Menia- Asyout- Beni Sweif & Alalbastar & Golden yellow and white \\
\hline Gray & Edfo- West of Menia & Teresta & Gray and smoked \\
\hline
\end{tabular}

Sources: Afia (1998) and other various sources. 
Figure 1: Location Of Marble Quarries And Marble Factories In Egypt

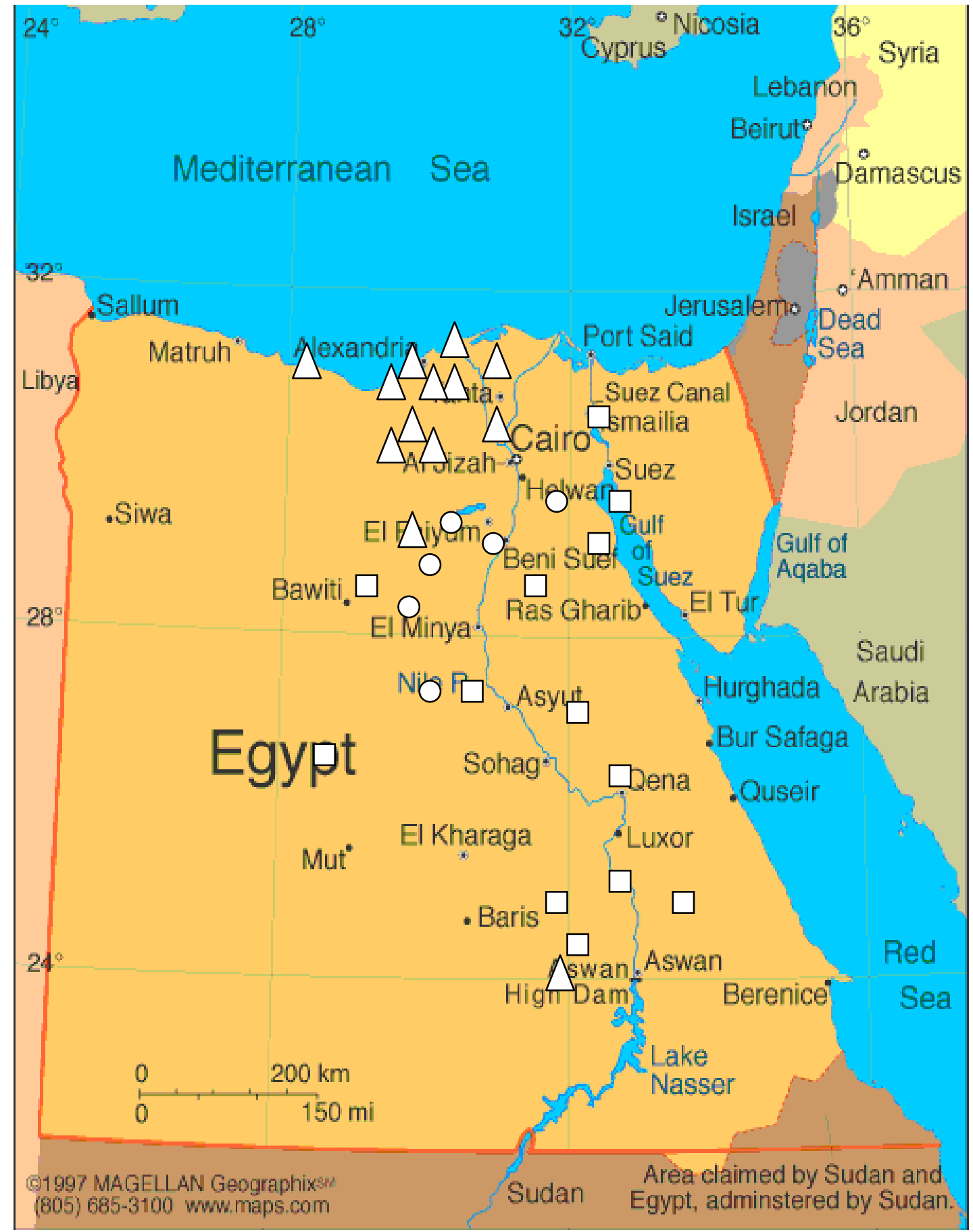

Source: Afia (1998). $\mp=$ Marble and Marbleized Limestone, $\Delta=$ Marble \& Granite Factories, $\circ=$ Alabaster. 


\section{NATURE OF COMPETITION AND REGULATIONS}

The marble industry in Egypt is highly competitive and has matured over the years after massive market entry since the early 1980s. About 500 factories and 3000 workshops compete to offer the consumer a product that is highly differentiated. On the demand side, customers of marble factories are either contractors who implement construction works for a big project or substantially smaller workshops which are price and quantity sensitive with varying degrees. On the supply side, quantity (capacity) competition exists where the suppliers who can provide scale quantities and/or who can operate their own quarries have a clear competitive edge over others. However, there is also tough price competition. Small suppliers sometimes dump the market by lowering their prices severely for the sake of generating cash. Market competition is highly differentiated by quality (vertical differentiation). This depends on target demand and whether the end user is local or production is done for export purposes. In addition, horizontal differentiation also exists (according to type and color of marble produced). There is hardly any seasonality in demand, yet the marble industry follows very much the business cycle of the construction sector with a lag. If the construction sector witnesses a boom, the marble industry is always expected to follow. There are several indirect barriers to entry: (1) lack of skilled workers, since there are no colleges or schools that qualify skilled workers to work in this industry, (2) relatively cheap imports mainly from Asia, (3) firm size since the industry is very space consuming and the optimum area for a marble processing unit is preferably not less than $5,000 \mathrm{~m}^{2}$, (4) location since the industry is characterized by regional concentration of factories, and (5) foreign exchange (lack of hard currency) for importation of capital machinery.

Though few factories in Egypt tend to acquire the latest technology, several factories still import second handed (sometimes outdated) machinery which is much lower in price. The main process which is highly automated is block cutting into plates, as doing this manually does not facilitate mass production. All other processes including polishing could be done either with fully automated equipment or with semi-automated or manual machines. Technologies are generally bought from Italy, Germany, Spain, India or Turkey. There are also some Egyptian machines that are produced in workshops copying the patent design of some of the imported machinery. These machines, though performing the required function, are comparatively inefficient and produce a non-standardized product that does not comply to internationally accepted standards. An important technological feature is the usage of diamond blades to cut hard stone. Diamond blades are quickly worn out after about three months of operation which imposes a high quasi fixed cost on factory owners. Another interesting feature of the industry is the intensive use of water. Water is used for cooling of saws, dust suppression and lubrication. The average water consumption for a middle size factory can go up to $60 \mathrm{~m}^{3}$ per hour of operation costing almost $\$ 10$ per hour.

Cost of extracting the stone could vary severely from one supplier to the other, depending on the type of technology used and tools utilized, as well as nature of the quarry. At the extreme lower end of pricing comes suppliers who intentionally use the cheapest and most wasteful way of extraction (dynamite and explosives). In that case, the social cost of losing valuable marble resources is not accounted for. This dumps prices in the market and causes a real distortion, and the difference in pricing is pushed on to society by wasting limited resources via low artificial prices and high social opportunity costs. This produces negative social returns since low product price is coupled with a high social cost. There are no regulations in force that control the stone cutting process or the percentage of waste acceptable to the authorities from the quarrying or extraction operation. In essence, the pricing of marble depends on several criteria including type, quality and rareness of the marble, i.e. the higher quality of marble and/or more rare the type is, the more expensive it becomes. However, rare types are priced according to demand based on maximum consumer willingness to pay. According to marble traders, selling a shipment of imported marble with rare colors relative to the types available in Egypt is done at a price five times higher than the bottom price initially set for the shipment. Pricing also depends on whether the marble is local or imported. In principle, imported marble is higher in price than locally produced marble. In addition, pricing is dependent on thickness. The default thickness is $2 \mathrm{~cm}$ or $4 \mathrm{~cm}$. There exists an implicit market rule that a $4 \mathrm{~cm}$ thick marble piece is priced 1.8 times a 2 $\mathrm{cm}$ piece.

There are several regulations that organize the marble quarrying industry in Egypt. First, the quarrying license is obtained from the governorate where the quarry is located. The license to operate a quarry is granted for one 
year and is renewable. When renewal is due, renewal fees have to be paid within 15 days. A standard measurement for any quarry is $100 \mathrm{~m} \times 50 \mathrm{~m}$. A businessman can operate more than one quarry and obtain more than one license. Second, the fees for a quarrying license vary between $\$ 770$ and $\$ 3,500$, depending on the governorate and location of the quarry. Third, a license to operate a quarry gives the license holder the right to get a certain quota of dynamite for marble extraction from the quarry. Fourth, the governorate is not responsible to supply the quarry with any infrastructure. It is the responsibility of the applicant to provide necessary basic needs to workers in the quarry, as well as needed water and electricity. This is the main reason for labor misallocation from a social standpoint. Fifth, on every truck loaded from the quarries, the tonnage is registered and a fee is paid on the amount of extracted marble. Fess paid vary from one governorate to the other. Sixth, there are no environmental waste regulations for marble extraction. Overall, current regulations are very limited and do not account for social costs of allocation, but on the other hand, such ineffective regulation implicitly invites entry.

The Egyptian marble industry could be one of the most rewarding industries in the Egyptian industrial economy if regulated properly. Yet, several impediments face the development of this industry. In essence, there is the misuse of marble quarries by suppliers which results in environmental waste especially in the extraction phase of production. Also, there is lack of infrastructure and attention given to the existing marble factories. An area like Shak El Thobaan, where over $80 \%$ of the marble industry is concentrated, does not have minimum basic infrastructure, such as supply of clean water. Accordingly, tanks of water are sold to the factories to be able to run their operation which creates a large overhead cost directly proportional to the variable cost of labor. In addition, distortions in the market exist caused by different extraction techniques which vary in efficiency. An inefficient marble producer who causes lots of waste to the country's resources by using cheap extraction techniques based on explosives can afford to offer the products much cheaper on the market causing price distortion, not only locally, but in the export markets as well. This destroys the reputation of the Egyptian marble in the international market. Additionally, the geographical location of the factories are far away from the marble quarries. There is concentration of factories in Cairo with no efforts to promote this industry in cities which lie closer to the quarries, such as cities located at the Red Sea. This increases the cost of the final product through high transportation cost and concentrates the labor movement and expertise in limited places. Moreover, there is lack of technical data on types of marble quarries in Egypt and existing deposits of marble, lack of organized training of manpower to service the industry, and lack of research and development efforts within the industry.

\section{TECHNICAL ANALYSIS}

Based on industry structure and representative firm analysis, we assume a generalized Cobb-Douglas production function of the form:

$$
Q(K, L)=A K^{\alpha} L^{\beta}
$$

where $K$ represents capital in thousands of US\$ and $L$ represents number of workers (labor). The coefficients $\alpha+\beta$ represent Returns to Scale (RTS) in production ${ }^{1}$.

Standard optimization yield factor input demands, which are dependent on the annual wage $w$ per person per year and annual opportunity cost of capital $r$, as given by:

$$
K^{*}=\left(\frac{\alpha w}{\beta r}\right)^{\frac{\beta}{\alpha+\beta}}\left(\frac{Q}{A}\right)^{\frac{1}{\alpha+\beta}}
$$

${ }^{1}$ If $\alpha+\beta>1$, then this represents Increasing Returns to Scale (IRS) and mass production, if $\alpha+\beta<1$, this would represent Decreasing Returns to Scale (DRS) and multi-task production, and if $\alpha+\beta=1$ then this represents Constant Returns to Scale (CRS) with high complementarity between inputs. 


$$
L^{*}=\left(\frac{\beta r}{\alpha w}\right)^{\frac{\alpha}{\alpha+\beta}}\left(\frac{Q}{A}\right)^{\frac{1}{\alpha+\beta}}
$$

Hence:

$$
K^{*}=\left(\frac{\alpha w}{\beta r}\right) L *
$$

Then, the total cost function for production $T C^{*}=w L^{*}+r K^{*}$ can be estimated by:

$$
\begin{aligned}
& \log T C=-\frac{1}{\alpha+\beta} \log A[(\alpha-\beta)(\log \beta-\log \alpha)] \\
& +\frac{\beta}{\alpha+\beta} \log w+\frac{\alpha}{\alpha+\beta} \log r+\frac{1}{\alpha+\beta} \log Q
\end{aligned}
$$

This gives us the sensitivity of total cost to the wage rate $w$, interest rate $r$, and production capacity $Q$. From this, average cost and average productivity are calculated.

In addition to production calculations, we also estimate financial profitability indicators for a medium-size representative firm including Return on Investment (ROI), Internal Rate of Return (IRR), and External Rate of Return (ERR). Investment risk (beta coefficient) is estimated using Capital Asset Pricing methodology. The Internal Rate of Return (IRR) gives a pre-tax profitability index and is considered equivalent to the discount rate $(\rho)$ at which internal cash flows are re-invested for a zero present value:

$$
-I+\sum_{t=1}^{n} \frac{B_{t}-C_{t}}{(1+\rho)^{t}}=0
$$

On the other hand, the External Rate of Return (ERR) gives minimum guaranteed yield $\left(r_{e}\right)$ estimated by:

$$
(-I)\left(1+r_{e}\right)^{n}=\left(\sum_{t=1}^{n} \frac{B_{t}-C_{t}}{(1+r)^{t}}\right)(1+r)^{n}
$$

Return on Investment (ROI) gives undiscounted average yearly profit margins $\left(R_{I}\right)$ :

$$
R_{I}=\frac{\frac{n+1}{n} \sum_{t=1}^{n}\left(B_{t}-C_{t}\right)}{\sum_{t=0}^{n}\left[I-\frac{t}{n}\left(I-S_{v}\right)\right]}
$$

The estimated market risk of investment in a typical marble firm can be easily calculated using the CAPM model (Capital Asset Pricing Model), such that relative investment risk $(\beta)$ is calculated by: 


$$
\beta=\frac{E(r)-f}{m-f}
$$

where it is given that $f$ is the economy's risk free rate, $m$ the economy's market interest rate, and $E(r)$ the expected return on investment in the marble industry in specific, hence $\beta$ measures relative investment risk of the marble industry relative to investments in other sectors of the Egyptian economy ${ }^{2}$.

The table below summarizes our results for the technical analysis based on medium-size firm representation given the above equations and standard log-linear regression techniques:

Table 2: Economics Of Production For A Medium-Size Representative Firm In The Marble Industry In Egypt

\begin{tabular}{|c|c|c|c|}
\hline Valuation & Description & Value & Notes \\
\hline Cobb Douglas & $\begin{array}{c}\text { Cobb Douglas Production } \\
\text { Function }\end{array}$ & $Q(K, L)=K^{0.89} L^{1.33}$ & $\begin{array}{l}\text { Factor Input } \\
\text { Allocation } \\
\end{array}$ \\
\hline RTS & Returns to Scale & $\alpha+\beta=2.2$ & $\begin{array}{c}\text { This implies Increasing } \\
\text { Returns to Scale in } \\
\text { production }\end{array}$ \\
\hline $\mathrm{AP}_{\mathrm{L}}$ & Average Labor Productivity & $7,795 \mathrm{~m}^{2}$ per person per year & \\
\hline$w$ & Wage rate per year & $\$ 2,937$ & per person, per year \\
\hline$r$ & Opportunity cost of capital & $13.29 \%$ & $\begin{array}{l}\text { Accounts for the purchasing } \\
\text { power of money }\end{array}$ \\
\hline MRTS & $\begin{array}{l}\text { Marginal Rate of Technical } \\
\text { Substitution }\end{array}$ & $\$ 1000$ of $K$ for 7.5 units of $L$ & $\begin{array}{c}\$ 1000 \text { units of capital are } \\
\text { substitutable by } 7.5 \text { units of } \\
\text { labor }\end{array}$ \\
\hline $\mathrm{L}^{*}, \mathrm{~K}^{*}$ & $\begin{array}{l}\text { Conditional Factor Input } \\
\text { Demands based on Cost } \\
\text { Minimization }\end{array}$ & $\begin{array}{l}L^{*}=C_{1}\left(\frac{r}{w}\right)^{0.4} Q^{0.45} \\
K^{*}=C_{2}\left(\frac{w}{r}\right)^{0.6} Q^{0.45}\end{array}$ & $\begin{array}{l}\qquad \frac{K^{*}}{L^{*}}=0.67\left(\frac{w}{r}\right) \\
\text { (ratio of factor demands in } \\
\text { relation to the ratio of factor } \\
\text { costs) }\end{array}$ \\
\hline LRAC & Long Run Average Cost & $L R A C=\gamma Q^{-0.55}$ & $\begin{array}{c}\text { Declining LRAC } \\
\text { with market expansion }\end{array}$ \\
\hline IRR & $\begin{array}{l}\text { Is the discount rate at which the } \\
\text { present worth of investment } \\
\text { benefits equals that of its costs. } \\
\text { At this discount rate, the present } \\
\text { worth of investment is zero. }\end{array}$ & $49.16 \%$ & $\begin{array}{l}\text { IRR is higher than the } \\
\text { ongoing market interest rate } \\
\text { which is around } 9.5 \% \text {. This } \\
\text { indicates that internal return } \\
\text { is higher than cost of capital. }\end{array}$ \\
\hline ERR & $\begin{array}{l}\text { A measure of the minimum } \\
\text { guaranteed return on capital } \\
\text { investment. }\end{array}$ & $26.19 \%$ & $\begin{array}{c}\text { ERR < IRR } \\
\text { As ERR is a more } \\
\text { conservative approach in } \\
\text { investment valuation. }\end{array}$ \\
\hline ROI & $\begin{array}{l}\text { Is the ratio between average } \\
\text { yearly profit and average- year } \\
\text { investment. }\end{array}$ & $12.24 \%$ & A relatively subtle ROI. \\
\hline $\begin{array}{l}\text { Market Risk } \\
\qquad(\widetilde{\beta})\end{array}$ & $\begin{array}{c}\widetilde{\beta} \text { determines leverage (relative } \\
\text { market risk) i.e. relative to } \\
\text { other investment sectors in the } \\
\text { economy based on CAPM } \\
\text { methodology. }\end{array}$ & $\tilde{\beta}=0.72$ & Low risk. \\
\hline
\end{tabular}

${ }^{2}$ Here, $\beta=1$ implies that investing in the marble industry is of equal risk to other sectors in the Egyptian economy, whereas $\beta>1$ implies a more risky and $\beta<1$ implies a less risky investment than other sectors of the economy. 
Technical analysis shows a highly profitable industry yet with ineffective use of technology and misallocation of resources. Several interesting characteristics are evident. First, the industry shows returns to scale of an increasing nature such that increasing all factor inputs increases production capacity by a proportionality factor of 2.2. However, the cost structure shows decreasing average cost with entry. Hence, although there are increasing returns, the efficient scale of production has not been achieved for a typical enterprise. Second, factor inputs (labor and capital) are non-complementary. Production does not therefore follow Leontief technologies. Since every $\$ 1000$ units of capital are generally substitutable by 7.5 units of labor, yet the average wage rate per unit of labor substantially exceeds such substitution ratio, then it is logical to propose that the industry should utilize less labor and more capital to become even more capital intensive than currently the case. This is a special case in a labor abundant country. Third, and what seems paradoxical at first, is that ROI $<r$. How come return on investment is strictly less than its opportunity cost? To answer such a paradox, one has to distinguish between internal return (IRR) and average return on investment (ROI) with the former a measure of internal generation of profits and the latter the nominal return on capital. In general, the following relationship exists: $I R R>E R R>r>R O I$. Since $I R R>r$ then investment is feasible and profitable. However, $R O I<I R R$ shows that more capital must be utilized in the form of added assets and/or more advanced technology for higher profitability. Thus, the current state of $R O I<r$ indirectly implies inefficient use of technology in production. Fourth, production obeys $Q(K, L)=K^{0.89} L^{1.33}$ with $\frac{K^{*}}{L^{*}}=0.67\left(\frac{w}{r}\right)$ such that relative factor allocation is lower than their relative costs. If such factor allocation is perceived as averages, then it must be true that relative labor allocation in specific is inefficient and needs to be reduced or replaced by other factor inputs since it can be inferred that $\underset{L, K}{\operatorname{MRTS}}<\frac{w}{r}$. This technical fact re-enforces our earlier discussion about labor misallocation and the need for more capital intensity in production. Fifth, long run cost is derived to be $C(Q)=f\left(Q^{0.45}\right)$ such that long run average cost is $L R A C=\gamma Q^{-0.55}$. Since economic profits are positive, then entry or expansion is profitable and attractive. Further, entry or capacity expansion reduces average cost. Hence, the effect of increasing returns in production overrides natural resource scarcity in that case. Last, by utilizing CAPM methodology, relative risk of investing in the marble industry is $\tilde{\beta}=0.72 \quad(\tilde{\beta}<1)$. This implies a low risk investment relative to other sectors of the Egyptian economy.

\section{GENERAL CONCLUSION}

In Egypt, the marble industry is still in development stage, in spite of its long history. The industry has the characteristics of monopolistic competition in terms of high degree of product differentiation whereas segmentation is driven by economies of scale and relative prices. Technical analysis shows increasing returns to scale in production with factor inputs being non-complementary. Major financial characteristics are high profit margin, low leverage, and asset durability.

The industry has good potential to prosper and to be one of the driving forces for the country's overall economic well-being especially as natural resources abound. Regulating this important resource of the country is mandatory for sustainable development especially regarding current outdated technological practices in marble extraction and necessary inclusion of adequate infrastructure facilities for better labor allocation. In the short run, these two aspects are the most critical in transforming the industry to a different level, i.e. such that private returns do not override social opportunity costs. In the long run, the industry requires drastic tranformation including movement from a leader-follower market mechanism towards spatial technological diffusion, a higher level of skilled human capital and associated R\&D activities, and more time for efficient market segmentation. High sustainable profitability may prove to attract more efficient production technology with entry. Overall, what is most interesting as a conclusion is that the marble industry in Egypt must become more capital intensive for higher productivity gains even though the Egyptian economy is undeniably labor abundant. 


\section{REFERENCES}

1. Afia, Mohamed Samih. Current Mining Development. Egyptian General Authority for Books. 1998.

2. Annual Bulletin Of Industry And Foreign Trade. Volumes 1997-2003. Central Agency for Public Mobilization and statistics (CAPMAS), Cairo.

3. Arnold, Dieter. Building in Egypt: Pharaonic Stone Masonry. New York: Oxford University Press. 1991.

4. $\quad$ Bradley, Frederick. The Stone Industry Worldwide: Current State and Trends, Marble-Stat 2002.

Associazione Italiana, Panorama, 2002.

5. Egyptian General Survey And Measurement Authority. Public's Guide to Mines and Quarries. Ministry of Industry, March 1996.

6. Egyptian General Survey And Measurement Authority. Mines and Quarries in Six Years. Ministry of Industry and Mining, Volumes 1990/1991-1995/1996.

7. El Alfy, Tarek. Owner of El Alfy Marble, Shak El Thobaan, Katameya, November 2003: Personal Communication.

8. El Sheikh, Mohamed. Owner of El Sheikh Marble Factory, Shak El Thobaan, Katameya, June 2003: Personal Communication.

9. $\quad$ Gdm Stone Industries Handbook, 2000. marbleandmore.com.

10. Hosny, Khaled. Credit Officer, National Bank of Egypt, November 2003: Personal Communication.

11. Leivick, Joel. Carrara: The Marble Quarries of Tuscany. Stanford University Press. 1999.

12. Mannoni, Luciana. Marble: The History of a Culture. Facts on File Publications. 1985.

13. Marble Institute Of America (MIA). www.marble-institute.com.

14. Marble Professional Of The Vatican. www.litosonline.com.

15. Mubarak, Khalid. "A Lost Egyptian Treasure: The World Awaits Egyptian Marble”. Al-Ahram Newspaper, Article on Friday June 27, 2003.

16. National Bank Of Egypt. "Market Study on the Marble Industry in Egypt", Unpublished Manuscript, 2002.

17. Stone 2000. www.marbleandmore.com.

18. Watany, Magdy. Owner of Watany Marble Factory in Ismalia, June 2003: Personal Communication.

\section{DISCLAIMER}

Azza I. Kandil is Senior Financial Advisor at BDSSP of the Canadian International Development Agency (CIDA) and Tarek H. Selim is Assistant Professor of Economics at The American University in Cairo. The authors would like to especially acknowledge the Egyptian General Survey and Measurement Authority (EGSMA) in addition to various industry entrepreneurs which were not reluctant to provide data. Also, helpful comments were received from Geologist Mohamed Samih Afia and Professors Adel Beshai and Herb Thompson of the Department of Economics at the American University in Cairo. Several institutions provided help including the National Bank of Egypt and CIDA. Author contact information: akandil@bdsspegypt.net and tselim@aucegypt.edu. 
NOTES 